\title{
The impact of the diagnosis of tuberculosis through its social representations
}

\author{
O impacto do diagnóstico da tuberculose mediante suas representações sociais \\ El impacto del diagnóstico de la tuberculosis mediante sus representaciones sociales
}

Kamila Nancy Gonçalves da Gama'
ORCID: 0000-0001-5968-3879
lací Proença Palmeira'
ORCID: 0000-0001-9659-3565
Ivaneide Leal Ataíde Rodrigues'
ORCID: 0000-0001-9968-9546
Angela Maria Rodrigues Ferreira'
ORCID: 0000-0001-6321-7512
Claudia dos Santos Ozela'
ORCID: 0000-0001-9226-190X

'Universidade do Estado do Pará. Belém, Pará, Brazil.

How to cite this article:

Gama KG, Palmeira IP, Rodrigues ILA, Ferreira AMR,

Ozela CS. The impact of the diagnosis of tuberculosis through its social representations. Rev Bras Enferm. 2019;72(5):1189-96.

doi: http://dx.doi.org/10.1590/0034-7167-2017-0881

Corresponding Author:

Kamila Nancy Gonçalves da Gama Email: kamiladaagama@gmail.com

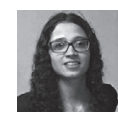

Submission: 03-09-2018 Approval: 04-26-2018

\begin{abstract}
Objective: To identify people's way of acting after the diagnosis of tuberculosis, through their social representations about the disease. Method: Qualitative and descriptive study based on the Theory of Social Representations, in which 23 patients of a school health center in Belém, PA, Brazil, participated. The software ALCESTE was used to generate a class concerning the impact of the diagnosis in people's lives. Results: The dimension of a new reality caused by the diagnosis of tuberculosis is linked with the image of dirt, (process of objectification) communicable/mortal disease that exclude, causing sorrow, despair and revolt (dimension of the affections), reverberating in the patients' actions (dimension of action). Final considerations: Patients have a global knowledge about tuberculosis, linking the knowledge of everyday life with the reified universe, pointing the multidimensionality of the phenomenon. The conclusion is that investing in the deconstruction of archaic beliefs about the tuberculosis that kills, replacing it with the curable tuberculosis, is necessary. Descriptors: Tuberculosis; Social Psychology; Diagnosis; Knowledge, Attitudes and Practice in Health; Psychosocial Impact.
\end{abstract}

\section{RESUMO}

Objetivo: Identificar o modo de agir das pessoas ante o diagnóstico da tuberculose, a partir de suas representações sociais sobre a doença. Método: Pesquisa qualitativa e descritiva embasada na Teoria das Representações Sociais, em que participaram 23 pacientes de um Centro de Saúde Escola em Belém (PA). Utilizou-se o software ALCESTE, gerando uma classe referente ao impacto do diagnóstico na vida das pessoas. Resultados: A dimensão do novo, decorrente do diagnóstico da tuberculose, se articula à imagem de sujeira, de doença transmissível/mortal e que exclui (processo de objetivação), causando tristeza, desespero e revolta (dimensão dos afetos), repercutindo nas ações (dimensão da ação) dos pacientes. Considerações finais: Os pacientes têm um conhecimento global sobre a tuberculose, articulando saberes do cotidiano aos do universo reificado, apontando a multidimensionalidade do fenômeno. Conclui-se sobre a necessidade de se investir na desconstrução de crenças arcaicas sobre a tuberculose que mata para a tuberculose que tem cura.

Descritores: Tuberculose; Psicologia Social; Diagnóstico; Conhecimentos, Atitudes e Prática em Saúde; Impacto Psicossocial.

\section{RESUMEN}

Objetivo: Identificar el modo de actuar de las personas ante el diagnóstico de la tuberculosis, a partir de sus representaciones sociales sobre la enfermedad. Método: Investigación cualitativa y descriptiva basada en la Teoría de las Representaciones Sociales, en que participaron 23 pacientes de un Centro de Salud Escuela en Belém (Pará, Brasil). Se utilizó el programa informático ALCESTE, que generó una clase referente al impacto del diagnóstico en la vida de las personas. Resultados: La dimensión de lo nuevo, derivada del diagnóstico de la tuberculosis, se articula a la imagen de suciedad, de enfermedad transmisible/mortal y que excluye (proceso de objetivación), causando tristeza, desespero e indignación (dimensión de los afectos), lo que repercute en las acciones (dimensión de la acción) de los pacientes. Consideraciones finales: Los pacientes tienen un conocimiento global sobre la tuberculosis, que articula saberes del cotidiano a los del universo reificado, señalando la multidimensionalidad del fenómeno. Se concluye acerca de la necesidad de invertir en la desconstrucción de creencias arcaicas de la tuberculosis que mata a la tuberculosis que tiene cura.

Descriptores: Tuberculosis; Psicología Social; Diagnóstico; Conocimientos, Actitudes y Práctica en Salud; Impacto Psicosocial. 


\section{INTRODUCTION}

Tuberculosis is a millenary disease, which, since its appearance, causes concern to humanity and still has high magnitude and importance in the world, even being an infectious disease that is preventable and curable ${ }^{(1)}$.

Tuberculosis was represented for centuries as a mortal disease, result of a life of overeating, which affected people who lived outside society's standards, were regarded as bohemian people, had high consumption of alcohol and tobacco, and, thus, should be socially excluded. In a more recent representation, the disease started being associated with a state of social misery, subjecting patients to rejection and discrimination, since nobody wants to be labeled as a miserable or be socially isolated ${ }^{(2)}$. These representations have contributed to the construction of a stigmatized social imaginary about disease and, consequently, to the way it is seen currently in society.

About 10.4 million people were affected by tuberculosis in 2015, and more than 1 million died because of the disease, being recognized as the infectious disease of greater mortality in the world, surpassing the sum of deaths caused by SIDA and malaria. In 2016, 66.796 new cases of the disease were diagnosed and recorded in Brazil, 41.8/100.000 inhabitants being diagnosed in the North, 39.3/100.000 inhabitants in the state of Pará and 75.2/100.000 inhabitants in the city of Belém, Pará, being one of the national capitals with tuberculosis incidence rate above the national value of $32.4 / 100.000$ inhabitants $^{(3)}$.

Besides being a public health problem, its severity has increased in recent decades due to its association with the human immunodeficiency virus (HIV), its resistance to many medicines and the biopsychosocial problems that it causes, such as stigma, fear and prejudice ${ }^{(4)}$.

Therefore, the access to the social representations of tuberculosis patients about the disease is required to deconstruct stigmas and misconceptions that still remain today, mobilizing affects and changing patients' attitudes concerning tuberculosis.

The social representations about tuberculosis were influenced by a new knowledge of the disease from the $20^{\text {th }}$ century on. Before that, these representations characterized it as a repulsive disease, leading the patient to a sort of exile, because his/her disease was seen as a character flaw ${ }^{(5)}$. Excluding the patient with tuberculosis was a way to avoid contamination, being one of the most painful consequences of the disease ${ }^{(6)}$.

The thought that the treatment of tuberculosis is difficult - due to the side effects of medication, which limit patients' routine, isolating them from society - strengthens the representation of the disease as something that limits the patient's work activities, as well as the idea that the suffering inflicted selects the strongest individuals, i.e. those who can complete the treatment ${ }^{(7)}$.

Thus, the fear of death and of being rejected by the others is considered the most profound mark caused by the diagnosis of tuberculosis, triggering various problems, even before a definitive diagnosis, generated by ideas (pre)conceived on the disease. When the name tuberculosis is revealed, an impact whose magnitude is possibly related to previous constructions on the disease occurs. This situation was often observed during the assistance provided to people who received the diagnosis of this disease, whose actions expressed several feelings regarding the fact that they knew they were sick.

The three dimensions of the social representations allowing a dimensional analysis are: information (concept), the field of representation (image) and the attitude. The information corresponds to the organization of the knowledge of a particular group about a social object, varying according to the quantity and quality of this knowledge. The field of representation alludes to the idea of image, of social model, to a specific content related to a specific aspect of the object of the representations, namely the organization of elements already structured in the representation. The attitude consists of the orientation of behavior that one has about the object of the social representation, showing the emotional reactions of the subjects and impacting on their actions regarding this object ${ }^{(8)}$.

When thinking about the subjectivity expressed in the individuals' actions and reactions after the diagnosis of the disease, the need for recognizing its social representations arises. The basis for such recognition is the premise that life in groups has symbolisms related to the culture, from which social representations arise, traditions and ways to act inherited from interpersonal relationships over time ${ }^{(9)}$. From this point (imagery dimension), the new situation (not familiar) creates social representations, mobilizing affects and determining behaviors concerning the object of this study: the way people act after the diagnosis of tuberculosis.

This study is important because the national scientific production has some gaps regarding this topic, which is evidenced when searching the state of the art. Using the databases LILACS, MEDLINE, BDENF and CEPEN, 117 studies, performed between 2010 and 2017, on the social representations of the tuberculosis were found ${ }^{(7,10-11)}$. This result showed the topic is explored in general, despite the gaps in the production of knowledge about the actions and reactions of people when faced with the diagnosis of tuberculosis (the new situation), which is corroborated by studies that could address the totality of the object in question.

This study uses the Theory of Social Representations (TSR) as support for interpreting the subjective dimension, i.e. the cognitive aspect of the individuals responsible for determine their social practices and attitudes when facing something represented. The background is important, for it enables the understanding of how the patient assimilates the events, as well as of how they are understood and disseminated in his/her social circle ${ }^{(8)}$.

In addition, tuberculosis is a phenomenon of social representation, as well as a serious social problem, because the history of the disease is associated with terror, death and isolation, aspects that still resonate in contemporary times. Thus, the actions and reactions of people after diagnosis is addressed, showing the context in which they are inserted, with respective behaviors for their health and preservation of their social group, constituting a mechanism capable of generating successful interventions in the fight against the disease.

Based on the premise that people's experiences and their previous conceptions are not dead, but active, by changing and filtering their experiences and current ideas ${ }^{(12)}$, the attempt to identify the way people act after the diagnosis of tuberculosis was made through the social representations of this disease, produced by the idea of severity, isolation and risk of death associated with the history of the disease. 


\section{OBJECTIVE}

To identify the way people act after the diagnosis of tuberculosis, through social representations about the disease.

\section{METHOD}

\section{Ethical aspects}

This study was approved by the Research Ethics Committee of the undergraduate degree in nursing from the State University of Pará (UEPA). Participants signed the informed consent form, and their identities were preserved through the use of alphanumeric codes, composed by the letter $P$ (patient) followed by the sequential number of the interview.

\section{Theoretical-methodological framework}

The Theory of Social Representations was used in its psychosocial perspective ${ }^{(8)}$. Social representations are understood as a set of explanations, beliefs and ideas that allow characterizing or identifying a given event, person or object, which, for resulting from the social interaction, are forms of knowledge built and shared by a group through behaviors, values, images and the positioning of their individuals regarding the object represented. Based on this fact, using this concept in this study is relevant.

\section{Type of study}

Descriptive study with a qualitative approach, based on procedural approach of the TSR.

\section{Methodological procedures}

\section{Study scenario}

This study was conducted in a school health center in Belém, Pará, Brazil, considered reference in the control of tuberculosis in the city.

\section{Data sources}

The information pertaining to the clinical data of the participants of the study were collected from secondary sources, such as the book of registration and control of tuberculosis patients. Out of 26 patients who were in regular treatment between September 2016 and March 2017, 23 met the criteria for inclusion and were included in this study. Two patients refused to participate in the study, and the third was in treatment for relapse.

The criteria for inclusion were tuberculosis patients of any age and gender, in treatment for at least one month. This treatment period was chosen because of the supposition that these patients would have some familiarity with the object of this study, but the disease still would be an unusual fact in their lives. Because of this, those who were in retreatment due to relapse or readmission after abandonment were excluded, because such conditions may generate biases for not being well accepted by patients, who need to struggle again to complete the treatment.

\section{Data collection and organization}

The approach of the participants occurred for convenience and was conditioned to their presence in the unit. They were invited to participate in the study at the end of the nursing consultation, being informed about the objectives of the study and asked about their interest in participating in it. In this case, they were directed to a doctor's office in the unit to an in-depth interview, paying attention to the preservation of secrecy, comfort, and privacy of participants. After signing the respective informed consent or acquiescence forms, as well as the consent for recording their statements in an electronic media (voice recorder), the interviews started. Patients who were not available for the interview at that moment were scheduled to do it another day in the unit.

The interviews lasted, on average, 30 minutes, with subjective questions for the understanding of the object of study, such as the perceptions and feelings regarding patients' diagnosis of tuberculosis. The data collection was performed from October 2016 to March 2017. Subsequently, statements were transcribed according to the guidelines by the software Alceste 2012.

\section{Data analysis}

The corpus was processed in the software Alceste, which makes a lexical analysis of a set of texts, while investigating the distribution of their vocabulary using sophisticated statistical methods ${ }^{(13)}$. The program divided the text into Elementary Context Units (ECUs), segmenting them into classes of words, whose meanings, nominations and interpretations were assigned based on the TSR. The analysis of the contents was performed through the Hierarchical Ascendant (HAC) and Descendant (HDC) Classifications.

\section{RESULTS}

The corpus submitted to the software Alceste generated 23 Initial Context Units (ICUs), segmented in 263 ECUs. These units were composed of 275 analyzable words, distributed in six classes according to frequency of occurrence (Chi-square) and the ECUs related to them, aiming at understanding their meanings based on the TSR. Each ICU had the profile data of the participants, such as sex, age group, level of education, religion, work and address, in order to characterize their social belongings.

In this analysis, the six classes approached the care of themselves, the impact of the diagnosis on the patients and on their social relations, the perception of the disease through the initial signs and symptoms, and the search for understanding the new process in their bodies. In this article, the focus will be the lexical class 4, consisting of 30 ECUs and 34 analyzable words, totaling $17 \%$ of the ECUs in the corpus. This class refers to a group predominantly female, aged between 25 and 34 years, having low monthly income, and of Catholic religion.

During the formation of the classes, the software first divided the corpus in two large blocks of classes. The first block generated the classes 1, 2, 3 and 4, being the classes 3 and 4 a subdivision of class 2, showing a strong closeness between them, because they have similar meanings (Figure 1). 


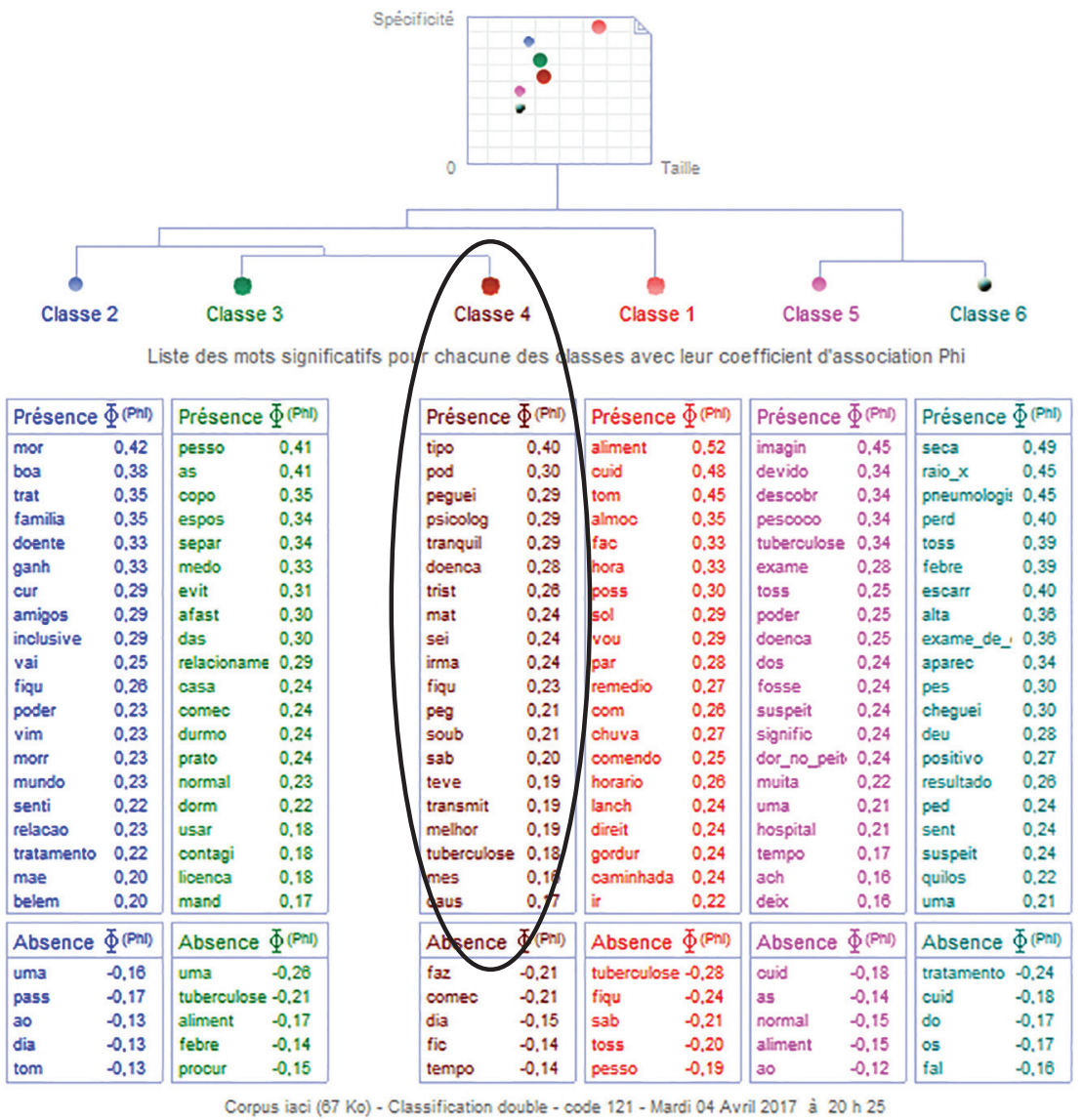

Figure 1 - Dendrogram and Hierarchical Descendant Classification of the classes generated by Alceste

In the first block, the class 1 distinguished itself from the others because it referred to the health care (care of themselves and of the other) exercised by participants. The class 2 assigns meaning to the disease in a social context and outside the family context, different from the classes 3 and 4 , which refer to the consequences and meanings of the disease in the social context of the tuberculosis patient, his/her insertion and interaction with his/her family (class 3), focusing on the dimension of the "other", as well as in the impact on the patient himself/herself (class 4),emphasizing the dimension of the "self".

The second block was divided, forming classes 5 and 6, which also have a strong closeness between them. Both focus on the (pre)discovery of the disease and the search for diagnosis, but are different because class 5 highlights the symptoms of the disease, and 6 shows the search for diagnosis.

This points closenesses and similarities between the classes, but distinct meanings and ideas, justifying such segmentations, whose hierarchy of classes shows a semantic distance between the roots composing the blocks, despite these approximations.

The HDC of the class 4 (Figure 1) has more representative lexicons, which relate to psychosocial and subjective aspects regarding the impact of the diagnosis on people's lives. This is a relationship me-myself, an arousal of new feelings - thus, then unknown ones, evoked after diagnosis -, which takes shape through the object searched and points out the ways in which the participants build their opinions, knowledge and ways to act faced with the disease.
Two groups are highlighted in the HAC (Figure 2): the first has the word "knew", related to the term "type", being both terms connected to the word "cause". The latter, in turn, is linked with a second group, of the terms "catch" and "sad". These relationships express the conceptions about the disease and the feeling of sadness after confirming the diagnosis of tuberculosis.

The ECUs of this class and the association between their lexicons show a sort of protagonism and proactive move from tuberculosis patients in an attempt to understand, in the current moment, the cause of the sickness and the psychosocial consequences of this process, showing the impact of the diagnosis on the lives of the diagnosed people. This impact, in turn, is influenced by the knowledge baggage of tuberculosis each person has. This understanding can be identified when the interviewees use the verbs "to know" and "to take" and the adjectives "tranquil", "sad" and "terrified". This proactive move leads to elements that represent what life with tuberculosis is, based on their previous knowledge of the disease, its history and the patients' social relationship.

In the ascendant lexical analysis, "I caught" and "disease" are linked with the terms "six", "months", "had" and "could". It means that, in an attempt to understand the process that they are experiencing, patients mobilize knowledge of the disease and affections to assign meaning to the sickness.

Up to now, I don't know how I caught it, it could have been on the bus or a badly healed flu. I was surprised because I did not know how I caught it. I just wanted to understand how I caught it, to be more careful, but as I know that it has a right treatment nowadays and the chances of dying are lower, I feel more tranquil. (P6, ECU Number 63)

I was in doubt on how I catch this disease, because I am very careful with cleaning, such as washing my hands. I remember when I had an accident in the street and the people threw a filthy cleaning flannel on my face, but I think it is hard to transmit like that, quickly. (P9, ECU Number 112)

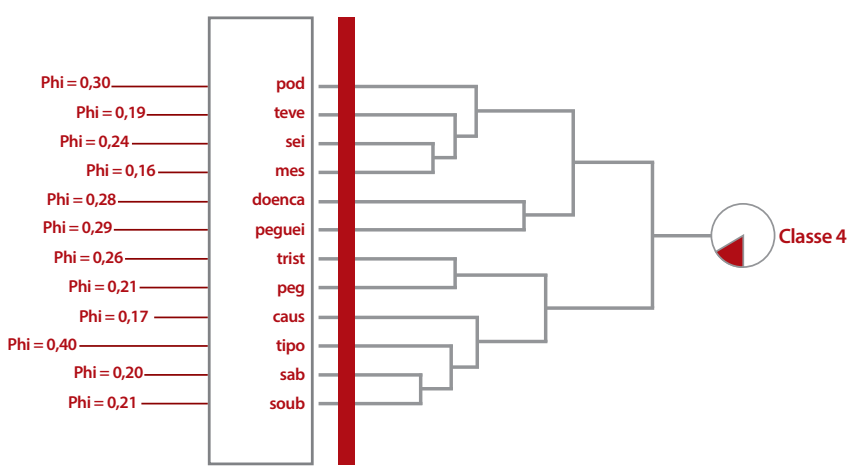

Figure 2 - Hierarchical Ascendant Classification of the class 4 
What I know about tuberculosis is that you have to take the medicines correctly because not taking them is dangerous, because of relapse. I know the treatment lasts six months, which is communicable only as in the case of my sister, who had tuberculosis in the lung. The psychologist and the nurses from here told me these things. (P18, ECU Number 217)

The term "type" cited by the participants is correlated with the words "thought", "treatment" and "tuberculosis" in the ECUs, when participants sought to give meaning to the process they lived.

Maybe this type of thought arouses because of the past, when there was no treatment and people were excluded. I was sad when I knew what it was, because I never thought it would happen to me, but then I felt better, because I knew I could catch it anytime at work. (P10, ECU Number 128)

I know that several types of treatment exist, but the one [type of treatment] I am doing lasts six months. (P15, ECU Number 181)

Then Ilearned that the type of tuberculosis I had is not communicable, I felt a little relieved, but knowing that you have tuberculosis is scaring, especially when you do not know much about the disease; I panicked because Idid not know what this disease was like. (P5, ECU Number 49)

When diagnosed with tuberculosis, doubts and uncertainties concerning the disease and its treatment are common on the part of patients, since it is something new (not familiar), causing people to associate it with the image of a mortal disease (image dimension) when elaborating their social representations, bringing the stigma and prejudice as a background, mobilizing affections and generating sadness, despair and revolt (affection dimension), reverberating in their actions and attitudes faced with the disease (dimension of action). Believing in a superior being contributes to the patients' positive view that they will be cured through the treatment. These feelings are expressed in the following statements:

Desperate, because I'm not from here. We came from Maranhão, so I was finishing my third year at school and I had to stop to come and do the treatment, because the place where l live do not provide this treatment, I had to change everything. (P2, ECU Number 18)

When it was confirmed that I had tuberculosis, I got very depressed because I had no knowledge of the disease and I thought this could never happen to me, because I believed that this disease had already been eradicated here in Brazil. (P20, ECU Number 228)

I got revolted, but then I realized I had a disease that has a cure, thank God. But anyway, this is not good; in the morning, you feel as if something is stealing your energies, making it difficult to get out of bed, because you are weak. (P8, ECU Number 94)

On the other hand, the fear of transmitting the disease to family members is one of the major concerns. Therefore, tuberculosis is interpreted as a disease that causes fear and exclude people.

When I received the result of the examination, I was tranquil, because I already knew it could be treated, I just wanted to know about transmission, out of consideration for my children, I did not want them to get sick too. (P1, ECU Number 5)
When I learned that I had tuberculosis, I was not terrified, I was sad because the treatment is tiresome and I confess that I was worried about who lives with me, especially about my daughter, who is eight years old. (P22, ECU Number 243)

Knowing that the disease is communicable causes the patients to fear the transmitting of it to their family members and to others, generating the prejudice and isolating them from people from their social circle. The following reports express the imaginary dimension of tuberculosis, as a disease that excludes, isolates and generates sadness.

That prejudiced thought crosses my mind, but then I reflect that I shouldn't belittle myself because I have tuberculosis. This occurs because tuberculosis is a disease that can be transmitted, and people still have a certain bias. This is so true that a person from my work came here to get information about what I had. (P17, ECU Number 202)

I realized that because I took a ride with him in his car and he asked if I was sick. When I told him I did, I noticed that he wanted me to get out of his car immediately, because he quickly opened the door for me. It made me feel sad. (P16, ECU Number 192)

Patients incorporate novelties derived from biomedical knowledge (reified universe) in their speeches, resulting from the professionals' orientations, whether it is present in their everyday conversations, in social media or in their previous experiences (dimensions of information). Thus, they are able to reframe their ideas and attitudes about tuberculosis, which encourages them to understand treatment as the only alternative for cure and improvement of symptoms:

When I learned of the treatment, I was worried because I did not know much about the disease, I only knew that it could kill me if I did not treat it, because I heard about it on television, but then I talked to the nurse, and she told me that it could be treated and I could be cured. So I relaxed, started to attend the appointments, had improvements by taking the medicines and realized that it was not that bad. (P16, ECU Number 188)

\section{DISCUSSION}

The participants' knowledge about tuberculosis is based not only on the clinical context, but also on the cognitive and affective contexts. The results show the dimension of the new situation, coming from the diagnosis of the disease, the unknown circumstance (not familiar), causing people to associate it with the image of "dirt" (image dimension) present in the ECUs when elaborating their social representations, - communicable and mortal (process of objectification) -, based on information circulating in the media, social spheres and previous experiences (information dimension). This imaginary dimension is impregnated of stigma and causes sadness, despair and revolt (dimension of affections), which echoes in daily life and its practices (dimension of action).

Thus, guided by several feelings that emerged before the diagnosis, such as sadness, fear, dread and concern, the participants showed the imaginary history about tuberculosis in their testimonies, as a fatal disease that repels the people close 
to them, when love and care are what patients need the most. It shows the participant's knowledge comes from negatives experiences with the disease and from information broadcast by media and social spheres. Therefore, when confronted with an unfamiliar situation, they associate this condition with their previous knowledge, producing a representation of the disease as something frightening.

The imagery surrounding tuberculosis, which views it as a socially exclusive phenomenon, remains nowadays even with the advances of science related to treatment and cure. This imaginary creates negative representations, since it structures the knowledge that a certain group has in relation to a social object - in this case, the actions and reactions after the diagnosis of the disease ${ }^{(8)}$.

The moment of the diagnosis of tuberculosis leaves marks on the patients' life, because it is the occasion when they have a particularity they only witnessed in others and to which they felt immune. Thus, this "new" subject appears, looking forward for understanding this "unknown" situation so that he/she can live, treat his/her disease and keep living in society. However, this perception of reality can bring specters of archaic images to light, objectifying tuberculosis as death sentence and isolation $^{(14)}$, mobilizing affections and generating great psychic and spiritual suffering.

Thus, by presenting negative viewpoints on tuberculosis, their social groups and the construction of representations exposed in their conversations are revealed, having stigma and prejudice as a common thread. As a consequence, in addition to the changes in the fulfillment of the patients' needs, psychological and family problems are faced in their daily lives, due to the fact that tuberculosis is a stereotyped and stigmatizing disease, with a wide range of prejudiced associations and whose history shows social exclusion ${ }^{(15)}$.

Such situations can be understood as a barrier for coping with the disease, in which stigma and prejudice overshadow the therapeutic advances of the medicines, whose actions are capable of making sputum test results come back negative from the fifteenth day of treatment on and, consequently, make the transmission of the bacillus to others impossible ${ }^{(16)}$.

Social representations are a type of knowledge organized and shared in the social sphere, allowing individuals from a common group to build a shared reality to better understand something unknown. This understanding is provided mainly by commonsense meanings, guiding the conduct and perceptions of society members ${ }^{(8,17)}$. Thus, when faced with something unusual, rejection tends to occur at a first moment, and then the new situation becomes familiar, which allows understanding several social representations on the disease ${ }^{(12)}$, impacting on the way patients act (action dimension) after the diagnosis of tuberculosis.

Because of the fact that tuberculosis still generates stigma and prejudice, it causes causes negative changes in patients by transforming their family space and relationship with the world and with himself ${ }^{(11)}$. This occurs because these individuals suffer prejudice and discrimination on the part of people who live with them, as well as they discriminate themselves, allowing the social representations from their social circle to arouse, and excluding themselves ${ }^{(18)}$.
On the other hand, the knowledge that the disease can be cured and the motivation provided by faith encourage patients to complete the treatment. This knowledge usually comes from a previous experience with the disease, for having met someone affected by tuberculosis who was cured after completing the treatment. People who have this kind of knowledge are more likely to view the disease as any other one - which, if treated, can be cured -, favoring the adherence to treatment ${ }^{(19)}$.

Therefore, the new information from the reified universe, integrated in the orientations on the disease provided by the health professionals for patients, have a key role at the moment of the diagnosis, because the former can disseminate this knowledge in their habitual conversations and favor the construction of the understanding of the object, which contributes to changes in negative and stigmatizing opinions. Hence, a bond between the health professional and the patient is essential to the offer of a coherent care, meeting the individual's real needs and understanding his/her particularities for the provision of orientations and information on the disease, as well as for spotting and deconstructing negative opinions, once knowledge positively impacts on the prevention practices and self-care ${ }^{(20)}$.

In sum, the orientations provided for patients contribute to the adherence to treatment, because these individuals acquire a better knowledge on the disease and on how to defeat it. In general, information provided for patients by health professionals in the medical consultations or in the outpatient of the Directly Observed Treatment (DOT) have proven to be essential for changing negative social representations on tuberculosis to a perspective of curable disease ${ }^{(21)}$.

\section{Study limitations}

The limitation of this study refers to its performance in a single scenario, which reduced the number of participants and prevented a broader comparative analysis among the populations of the various Basic Health Units in Belém, PA, Brazil, that has a program to control tuberculosis.

\section{Contributions to the nursing field}

Nurses work directly in the program to control tuberculosis, being constantly involved with the diagnosed people. As a consequence, knowing the patients' social representations about tuberculosis, despite being important for the entire multi-professional team, is even more important for nurses, since they allow them to understand the motivations and fears faced by patients after the diagnosis of tuberculosis. Thus, nurses will be able to provide a more effective care for these patients and focus on the real problems presented.

\section{FINAL CONSIDERATIONS}

The contents justifying the actions and reactions of people when being diagnosed with tuberculosis are influenced by the social memory of the disease and are associated with the image of "dirt", transmission and death, affecting the dimension of patients' affections and expressed in thoughts of sadness, despair and revolt externalized through actions and attitudes. 
Information from social sphere are a background for the social representations on tuberculosis, having feelings and images strongly associated with fear, shame, prejudice and death, which are disseminated from generation to generation, producing stigma and negation of the disease by patients.

Demystifying these negatives representations on a millenary disease is not an easy task. Consequently, studies aimed at accessing their deconstruction and the actions and reactions on the part of those diagnosed with tuberculosis are extremely important to establish interventions focused on patients' real health that break down prejudices and make the knowledge of the disease accessible to the population.

Therefore, the health education provided by health professionals, including nurses, is important to replace negative thoughts with conceptions for allowing the patient to be integrated in society and adhere to treatment, as well as contributing to reduce stigma and prejudice linked with this pathology and with the people affected by it.

\section{REFERENCES}

1. World Health Organization-WHO. Global strategy and targets for tuberculosis prevention, care and control after[Internet]. Geneva (CH):WHO; 2013[cited 2015 Oct 30]. Available from: http://www.who.int/tb/post2015_tbstrategy.pdf

2. Pôrto A. Social representations of tuberculosis: stigma and prejudice. Rev Saúde Pública[Internet]. 2007[cited 2015 Nov 5];41(Suppl1):43-9. Available from: http://www.scielo.br/pdf/rsp/v41s1/en_6493.pdf

3. Ministério da Saúde (BR). Indicadores prioritários para o monitoramento do Plano Nacional pelo Fim da Tuberculose como problema de saúde pública no Brasil. Bol Epidemiol[Internet]. 2017[cited 2017 Feb 5];48(8):1-11. Available from: http://portalarquivos.saude.gov.br/ images/pdf/2017/marco/23/2017-V-48-N-8-Indicadores-priorit--rios-para-o-monitoramento-do-Plano-Nacional-pelo-Fim-da-Tuberculosecomo-Problema-de-Sa--de-P--blica-no-Brasil.pdf

4. Barbosa EL, Levino A. [Analysis of TB/HIV coinfection as development factor for multidrug resistant tuberculosis: a systematic review]. Rev Pan-Amaz Saúde[Internet]. 2013[cited 2016 Jun 5];4(4):57-66. Available from: http://scielo.iec.gov.br/pdf/rpas/v4n4/v4n4a07.pdf Portuguese.

5. Ferreira JT, Engstrom EM. [Fear, danger, stigma: social representations of drug users and/or dealers affected by tuberculosis and healthcare]. Saúde Soc[Internet]. 2017[cited 2018 Feb 25];26(4):1015-25. Available from: http://www.scielo.br/pdf/sausoc/2017nahead/1984-0470sausoc-s0104-12902017155759.pdf Portuguese.

6. Dodor EA. The feelings and experiences of patients with tuberculosis in the Sekondi-Takoradi metropolitan district: implications for TB control efforts. Ghana Med J[Internet]. 2012[cited 2018 Feb 25];46(4):211-8. Available from: https://www.ncbi.nlm.nih.gov/ pubmed/23661839/pdf/GMJ4604-0211.pdf

7. Silva EA, Silva GA. [Perceptions of living with tuberculosis: a study on social representations of people in treatment]. Physis[Internet]. 2016[cited 2018 Feb 26];26(4):1233-47. Available from: http://www.scielo.br/pdf/physis/v26n4/1809-4481-physis-26-04-01233.pdf Portuguese.

8. Moscovici S. A psicanálise, sua imagem e seu público. Petrópolis (RJ):Vozes; 2012.

9. Jovchelovitch S. Os contextos do saber: representações, comunidade e cultura. 2nd ed. Petrópolis (RJ):Vozes; 2011.

10. Souza SS, Silva DMGV, Meirelles BHS. Social representations of tuberculosis. Acta Paul Enferm[Internet]. 2010[cited 2018 Mar 6];23(1):23-8. Available from: http://www.scielo.br/pdf/ape/v23n1/en_04.pdf

11. Clementino FS, Martiniano MS, Clementino MJSM, Sousa JC, Marcolino EC, Miranda FAN. [Tuberculosis: uncovering personal and social conflicts]. Rev Enferm UERJ[Internet]. 2011 [cited 2016 Apr 6];19(4):638-43. Available from: http://www.facenf.uerj.br/v19n4/v19n4a23.pdf Portuguese.

12. Moscovici S. Representações sociais: investigação em psicologia social. 11th ed. Petrópolis (RJ):Vozes; 2015.

13. Azevedo DM, Miranda FAN. [The social representations theory and ALCESTE: theoretical-methodological contribution in qualitative research]. Saude Transf Soc[Internet]. 2012[cited 2017 Apr 15];3(4):4-10. Available from: http://incubadora.periodicos.ufsc.br/index.php/ saudeetransformacao/article/download/1588/2235

14. Oliveira LCS, Nogueira JA, Sá LD, Palha PF, Silva CA, Villa TCS. [The discourse of individuals on feelings associated with coping with tuberculosis]. Rev Eletr Enferm[Internet]. 2015[cited 2017 Apr 5];17(1):12-20. Available from: https://www.fen.ufg.br/fen_revista/v17/n1/pdf/ v17n1a01.pdf

15. Sá LD, Santos ARBN, Oliveira AAV, Nogueira JA, Tavares LM, Villa TCS. Providing health care to women with tuberculosis: the family focus perspective. Texto Contexto Enferm[Internet]. 2012[cited 2017 Jun 2];21(2):409-17. Available from: http://www.scielo.br/pdf/tce/v21n2/ en_a20v21n2.pdf

16. Ministério da Saúde (BR). Tratamento diretamente observado (TDO) da tuberculose na atenção básica: protocolo de enfermagem[Internet]. Brasília (DF):Author; 2011 [cited 2015 Nov 6]. Available from: http://bvsms.saude.gov.br/bvs/publicacoes/tratamento_diretamente_ observado_tuberculose.pdf

17. Jodelet D, editor. As representações sociais. Rio de Janeiro (RJ):EdUERJ; 2001. 
18. Chirinos NEC, Meirelles BHS, Bousfield ABS. Relationship between the social representations of health professionals and people with tuberculosis and treatment abandonment. Texto Contexto Enferm[Internet]. 2017[cited 2017 May 23];26(1):e5650015. Available from: http://www.scielo.br/pdf/tce/v26n1/0104-0707-tce-26-01-5650015.pdf

19. Hino P, Bertolozzi MR, Takahashi RF, Egry EY. Health needs according to the perception of people with pulmonary tuberculosis. Rev Esc Enferm USP[Internet]. 2012[cited 2017 May 23];46(6):1438-45. Available from: http://www.scielo.br/pdf/reeusp/v46n6/en_22.pdf

20. Queiroz AAR, Dantas DNA, Lopes RH, Menezes RMP, Enders BC, Arcêncio RA. Knowledge of the families of patients with tuberculosis regarding this disease: a transversal study. Cogitare Enferm[Internet]. 2016[cited 2017 May 23];21(1):1-9. Available from: http://revistas.ufpr. br/cogitare/article/download/42136/27648

21. Silva Jr DN, Silva YR, Silva AKV, Lima FAQ, Nascimento EGC.[Access, and relationship adherence to treatment for tuberculosis under the perspective of users and family]. Rev Universidade Vale do Rio Verde[Internet]. 2014[cited 2017 Jan 10];12(2):676-94. Available from: http:// periodicos.unincor.br/index.php/revistaunincor/article/view/1517/pdf_246 Portuguese. 